Veli-Matti Vesterinen is a Ph.D. student at the Chemistry Education Centre at the University of Helsinki, Finland. His study interests include the philosophy of chemistry, the nature of chemistry, and the aims of chemistry education.

Professor Maija Aksela is the Head of the Chemistry Education Centre at the University of Helsinki, Finland. Her study interests include meaningful chemistry learning, higher order-thinking skills, and computer- assisted chemistry education.

Markku R. Sundberg is a senior lecturer of inorganic chemistry at the University of Helsinki. His main interests lie on general theories in chemistry and more specifically chemical bonding.

VELI-MATTI VESTERINEN

Chemistry Education Centre, Department of Chemistry, University of Helsinki, Finland veli-mattivesterinen@helsinki.fi

MAIJA AKSELA

Chemistry Education Centre, Department of Chemistry, University of Helsinki, Finland maija.aksela@helsinki.fi

\title{
Nature of Chemistry in the National Frame Curricula for Upper Secondary Education in Finland, Norway and Sweden
}

\begin{abstract}
The aim of this study was to discover how current chemistry syllabi in the frame curricula for upper secondary education in three Nordic countries (Finland, Norway, and Sweden) take into account topics related to the nature of chemistry. By qualitative content analysis, the statements related to the nature of chemistry were divided into categories. Conclusions and implications for improving the frame curricula under study were made by comparing results with research into the nature of science. Chemistry syllabi from the Nordic frame curricula analyzed take into account the aims related to the nature of chemistry in a very similar manner. The ideas that should be made more explicit in all of the analyzed curricula are: i) the limits of the chemical models and theories, ii) the relationship between chemistry and other natural sciences, iii) the importance of creativity in chemical research, iv) the concepts of evidence in science texts, v) the social nature of chemical research, and vi) chemistry as a technological practice.
\end{abstract}

\section{INTRODUCTION}

In Finland, Norway, and Sweden national frame curricula define educational aims for compulsory and upper secondary school education. Chemistry education should take into account not only ontological chemical knowledge, i.e. knowledge about chemical compounds, concepts and models, but also philosophical and sociological perspectives related to chemical practice and reflection on the role of chemistry in society (Krageskov Eriksen, 2002). During this century there has been a growing interest in the application of the philosophy of chemistry in chemical education (e.g. Erduran, 2001; Erduran \& Duschl, 2004; Lombardi \& Labarca, 2007; Scerri, 2003). This study takes a domain-specific approach (see Erduran \& Scerri, 2002) by examining how chemistry syllabi of curricula take into account ideas related to the nature of chemistry. 


\section{Nature of science and nature of chemistry}

Scientific and technological literacy are widely considered as important goals for education (Hodson, 2003). As part of scientific literacy, the nature of science (NOS) is often seen at the core of the curricular aims of science education, both at the secondary and university level (Matthews, 2004).

Although there is no general agreement on the exact definition of NOS (Abd-El-Khalick, 1998), some efforts to define NOS have been made. In a Delphi style study Osborne, Collins, Ratcliffe, Millar, and Duschl (2003) consulted experts to find out the central 'ideas-about-science' that should be taught in school science. The nine central 'ideas-about-science' to be taken into account in science education were:

1. scientific method and critical testing

2. creativity

3. historical development of scientific knowledge

4. science and questioning

5. diversity of scientific thinking

6. analysis and interpretation of data

7. science and certainty

8. hypothesis and prediction

9. cooperation and collaboration in the development of scientific knowledge.

Based on their review of the literature on philosophy, sociology and history of science Lederman, Abd-El-Khalick, Bell, and Schwartz (2002) suggested including the following set of 'ideas-aboutscience' in science curricula:

1. the empirical nature of scientific knowledge

2. observation, inference and theoretical entities in science

3. distinction and relationship between theories and laws

4. the creative and imaginative nature of scientific knowledge

5. the theory-laden nature of scientific knowledge

6. the social and cultural embeddedness of scientific knowledge

7. the myth of the scientific method

8. the tentative nature of scientific knowledge.

Excluding some differences on terminology, both studies recommend including a similar set of topics for science curricula. One notable difference is the 'scientific method', which is suggested as one of the central NOS topics by Osborne et al. (2003) and is seen as a myth by Lederman et al. (2002). (For detailed discussion on the differences see Niaz (2008).)

There are differences between all the scientific fields and the interdisciplinary field of the philosophy of chemistry highlights the domain-specificity of the nature of chemical knowledge (Erduran \& Scerri, 2002). Like any other field of science, chemistry is not just a collection of knowledge, but more of a culture, with learned patterns for thinking and acting transmitted through theory, skills and values (Dalgety, Coll \& Jones, 2003). According to McComas and Olson (1998), NOS can be seen as an amalgamation of four fields of science studies: the philosophy of science, the history of science, the sociology of science, and the psychology of science. Research published in journals devoted to philosophy of chemistry (HYLE - International Journal for Philosophy of Chemistry and Foundations of Chemistry) has shown interest in all of the aforementioned fields. In this study, nature of chemistry is defined as part of NOS, which includes the philosophical, historical, sociological, and psychological perspectives of chemical practice and reflection on the roles chemistry and chemistry education play in society. 
The nature of chemistry is not only related to scientific literacy and NOS. The focus of technology educations is moving from the skills involved in the fabrication of artefacts towards development of critical awareness of the technologically mediated world and the way technology shapes our future (Dakers 2006a). A modern technology curriculum should thrive for technological literacy based on the history, sociology and philosophy of technology and encourage critical debate about technology and the role that industry has in its development (Dakers 2006a). Of all the sciences, chemistry is perhaps most closely related to industry and technology (Laszlo, 2006, Schummer, 1999; Sjöström 2007), and thus the nature of chemistry also contains aspects of technological literacy.

In studies about teaching NOS there have been some suggestions for different pedagogical approaches to improving knowledge of NOS (e.g. Abd-El-Khalick \& Akerson, 2004; Akerson, Abd-ElKhalick \& Lederman, 2000; Bell, Blair, Crawford \& Lederman, 2003; Khishfe \& Abd-El-Khalick, 2002; Solomon, Duveen, Scot \& McCarthy, 1992; Vesterinen \& Aksela, 2009). Research by AbdEl-Khalick \& Lederman (2000) on the relative impact of implicit versus explicit approaches to addressing NOS shows that implicit approaches, which assume that 'doing science' would necessarily translate into enhanced understandings of NOS among students, are not as effective as explicit reflective approaches, which provide a framework for reflection enabling students to internalize NOS understanding.

\section{Nordic national frame curricula}

In Finland, Norway, and Sweden national frame curricula define educational aims for upper secondary schools. To study the nature of chemistry in Nordic education, the chemistry syllabi of the national frame curricula act as natural starting points for research. There is some research on the nature of science presented in integrated science curricula (e.g. McComas \& Olson, 1998), but the analysis of how chemistry curricula have taken into account the issues related to the nature of chemistry has not been carried out before. As the explicit approach is more effective in developing an understanding of the nature of science (Abd-El-Khalick \& Lederman, 2000), the topics explicitly taken into account in curricula are probably the ones that are most likely to be realized.

The Finnish national frame curriculum National core curriculum for upper secondary schools 2003 (Finnish National Board of Education, 2003) has been in use since 2003 in Finnish upper secondary schools, which prepare students for tertiary education. The Finnish frame curriculum includes a syllabus for five chemistry courses (one compulsory and four optional). Norway recently revised its national curricula for both compulsory and upper secondary education. We analyzed Chemistry - programme subject in programmes for specialization in general studies (Norwegian Directorate for Education and Training, 2006). The national frame curriculum includes a syllabus for two chemistry courses for Norwegian students preparing for tertiary education. From the Swedish frame curricula for upper secondary school programs we analyzed the most recent chemistry syllabus for the natural science programme Natural science programme GY 2000:14 (National Agency for Education, 2000). The natural science program includes three chemistry courses in chemistry (two compulsory and one optional course).

The aim of the present study is to investigate and compare the 'ideas-about-science' or 'ideasabout-chemistry' presented in the chemistry syllabi of the upper-secondary-education-level national frame curricula of Finland, Norway, and Sweden. We especially wanted to uncover, i) how the 'ideas-about-chemistry' presented in the national frame curricula under study differ from one another, and ii) how those ideas relate to ideas presented in the research literature. In our conclusions, we also make suggestions on how to improve the national frame curricula by better taking into account the most important aspects of the nature of science. 


\section{SAMPLE AND METHOD}

The main data sources were the upper secondary school chemistry syllabi of the Finnish, Norwegian and Swedish national frame curricula. In addition to the curricula under study we analyzed chemistry syllabi from the Finnish and Swedish national frame curricula for compulsory school education: National core curriculum for basic education 2004 (Finnish National Board of Education, 2004) and Syllabuses for the compulsory school (National Agency for Education, 2009). The Norwegian national frame curriculum for compulsory school education was not analyzed because the Norwegian frame curriculum has an integrated science syllabus rather than a separate chemistry syllabus in compulsory school.

Syllabi were qualitatively analyzed in three phases, along the lines described by Huberman and Miles (1994):

1. In the first phase, we reduced the data by selecting the statements related to philosophical, historical, sociological, and psychological perspectives on chemical practice and reflection on the role of chemistry and chemistry education as a part of society. As the topics explicitly taken into account in the chemistry syllabi of the frame curricula are very probably the topics that the teachers take into account in their teaching, only the statements that are explicitly related to the nature of chemistry were selected.

2. In the second phase, we produced a topology by organizing and assembling statements into categories. Although the analysis was done inductively, the validity of categories formed was evaluated during the analysis by comparing the formed categories to views presented in the research. Alongside description of the categories direct quotes from the data are provided.

3 . In the third phase, we made conclusions by comparing the three national frame curricula with each other and the ideas derived from previous research. Finally some recommendations for teacher education were made based on the results and literature.

\section{RESULTS}

Categories formed through content analysis were organized into two themes by connecting related categories. Themes were named: i) chemistry as an inquiry and ii) the social character and ethics of chemistry.

\section{Chemistry as an inquiry}

The first theme collects the categories related to scope and nature of chemical research. Topics mentioned explicitly in curricula are presented in Table 1.

Table 1. Topics related to scope and nature of chemical research taken into account in the chemistry syllabi of the national frame curricula for upper secondary education. Topics mentioned explicitly in the frame curriculum under study are marked.

\begin{tabular}{|l|c|c|c|}
\hline Topics & Finnish & Norwegian & Swedish \\
$\begin{array}{l}\text { Chemistry as research into the characteristics, structure and } \\
\text { function of substances }\end{array}$ & + & + & + \\
Models as a means of explaining chemical phenomena & + & + & + \\
The tentative nature of chemical knowledge & & + & + \\
The way theories and models affect experimental research & & + & + \\
Experimental research as a step-by-step-procedure. & + & + & + \\
\hline
\end{tabular}


All of the curricula define chemistry in a similar way as research into the characteristics, structure, and function of substances.

"Chemists research, determine and describe how substances are built up at a micro level, and on this basis explain their properties and how substances react." (Norwegian Directorate for Education and Training, 2006, p. 1.)

"The subject of Chemistry covers the properties, structure and function of chemical elements, as well as what takes place during chemical reactions."

(Sweden: National Agency for Education, 2000, p. 54.)

In all syllabi under study, theories and models are seen as a way of explaining chemical phenomena.

"Chemistry instruction is characterised by observation and experimental study of the properties of chemical phenomena and substances, the interpretation and explanation of phenomena by means of models and structures, description of phenomena using chemical notation and by modeling and mathematical processing of phenomena."

(Finnish National Board of Education, 2003, p. 156.)

"The school in its teaching of chemistry should aim to ensure that pupils (...) develop their ability to (...) describe, interpret, and explain chemical processes using natural scientific models."

(Sweden: National Agency for Education, 2000, p. 53.)

Scientific knowledge might be reliable and durable, but never absolute or certain. Models, theories and laws are subject to change. The tentative nature of scientific knowledge is seen as one of the central aspects of NOS (e.g. Abd-El-Khalick, 1998; Lederman et al., 2002; Osborne et al., 2003). The tentativeness of chemical models is acknowledged in the Norwegian and Swedish national frame curricula.

"The main subject area also gives an insight into how models have changed in the course of history."

(Norwegian Directorate for Education and Training, 2006, p. 2.)

The way the existing models affect the research setting and the observations made from experiment is acknowledged in the Swedish and Norwegian curricula (see Table 1).

"The development of the science of chemistry is the result of an interaction between experiment and theory. (...) Training in chemistry shall link theory with practical laboratory work. (...) It also deals with the fact that chemistry is a practical discipline that uses laboratory equipment and analytical processes, and how theories and models are tested and illustrated through experiments."

(Norwegian Directorate for Education and Training, 2006, pp. 1-2.)

"As in all the natural sciences, a knowledge and conceptual understanding of chemistry is developed through an interaction on the one hand between observations and experiments, and on the other theories and theoretical models."

(Sweden: National Agency for Education, 2000, p.54.)

All three curricula describe chemical research as a step-by-step recipe with more or less the same phases. The phases of research mentioned in curricula are presented in Table 2. The Finnish frame curriculum doesn't explicitly mention setting up a hypothesis, and the phase of defining a research question is only mentioned in the Swedish syllabus.

"The school in its teaching of chemistry should aim to ensure that pupils (...) develop their ability to handle chemical laboratory equipment, to choose, plan and carry out experiments, as well as make observations, describe, interpret, and explain chemical processes using natural scientific models. (...) Teaching of chemistry in the upper secondary school provides trai- 
Table 2. Phases of experimental research mentioned explicitly in the national frame curricula. Phases mentioned explicitly in the frame curriculum under study are marked.

\begin{tabular}{|l|c|c|c|}
\hline Phases of research & Finnish & Norwegian & Swedish \\
Defining a research problem & & & + \\
Forming a hypothesis & & + & + \\
Conducting an experiment & + & + & + \\
Observation and measuring & + & + & + \\
Interpreting the results and making conclusions & + & + & + \\
Evaluating the results and their reliability & + & + & + \\
Presenting the results & + & + & + \\
\hline
\end{tabular}

ning in scientific ways of working. This means formulating a question, setting up a hypothesis, testing it through experiments, processing and critically examining the results, and presenting these orally and in writing in correct language and terminology."

(Sweden: National Agency for Education, 2000, pp. 53-54.)

\section{The societal character of chemistry}

The second theme collects the categories related to societal character and ethics of chemistry. Topics mentioned explicitly in curricula are presented in Table 3.

Table 3. Topics related to the social character and ethics of chemistry taken into account in the chemistry syllabi of the national frame curricula for upper secondary education. Categories mentioned explicitly in the frame curriculum under study are marked.

\begin{tabular}{|l|c|c|c|}
\hline Topics & Finnish & Norwegian & Swedish \\
\hline Societal importance of the applications of chemistry & + & + & + \\
$\begin{array}{l}\text { Impact of chemical knowledge on our culture and worldview } \\
\begin{array}{l}\text { Chemical knowledge as a basis for societal and ethic } \\
\text { decisions and discussion }\end{array}\end{array}$ & + & + & + \\
Chemists make ethical decisions & & + & + \\
\hline
\end{tabular}

Every national frame curricula in this study is consistent with the view that students should understand the huge impact that the applications of chemistry have on our society. The Swedish syllabus (National Agency for Education, 2001) even concludes that chemistry education should aim to develop the students' ability to analyze and evaluate the role of chemistry in society.

"Instruction will convey an image of chemistry as one of the key natural sciences, which studies and develops materials, products, methods and processes in order to promote sustainable development."

(Finnish National Board of Education, 2003, p. 156.) 
"Chemists make an important contribution to the development of biotechnology, nanotechnology, medicine, pharmacy, environmental science, new materials and new energy sources. Through the programme subject, the individual shall acquire an insight into the significance of chemical research on technology and economic development. The programme subject shall help pupils understand how substances affect the environment, and how the development of new industrial methods can reduce strain on the environment. In this way, the programme subject can help focus on the environment and sustainable development."

(Norwegian Directorate for Education and Training, 2006, p. 1.)

"The subject of Chemistry aims at providing (...) a knowledge of the variety of chemical applications and their importance in everyday life, industry, medicine and the living environment. (...) The school in its teaching of chemistry should aim to ensure that (...) pupils develop the ability to analyse and evaluate the role of chemistry in society."

(Sweden: National Agency for Education, 2000, p.53.)

Impact of chemical knowledge on our culture and worldview was acknowledged in two syllabi.

"The historical development of the subject is part of our cultural heritage, and this should come across in the teaching."

(Norwegian Directorate for Education and Training 2006, p. 1.)

"The school in its teaching of chemistry should aim to ensure that pupils (...) acquire knowledge of the development of the history of ideas concerning chemistry, and how developments in chemistry have affected Man's world view and the development of society."

(Sweden: National Agency for Education, 2000, p. 53.)

All national curricula under study see chemical knowledge as a tool for making informed decisions on ethical and societal issues.

"The objectives of instruction in chemistry are for students to (...) know how to use their chemical knowledge as consumers in order to promote health and sustainable development and in discussions and decision-making processes concerning nature, the environment and technology." (Finnish National Board of Education, 2003, p. 156.)

"In addition, the subject aims at providing a knowledge of chemistry needed for the individuals from a natural science starting point to be able to participate in public debate, form their views on environmental issues, and contribute to a sustainable society."

(Sweden: National Agency for Education, 2000, p. 53.)

However only the Norwegian national frame curriculum addresses the ethical decisions that the chemists have to face.

"The programme subject shall make it clear that chemical research is subject to ethical criteria. (...) The aims of the studies are to enable pupils to (...) discuss how researchers ensure that research is ethically defensible."

(Norwegian Directorate for Education and Training 2006, p. 1-4.)

\section{DisCUSSION AND CONCLUSIONS}

In this section the results of the analysis are compared with the ideas derived from previous research into the topic.

\section{Chemistry as an inquiry}

The nature of chemical models and how they relate to the laws of physics has been discussed in the philosophy of chemistry for quite some time (e.g. Friedrich, 2004; Ostrovsky, 2001, 2005a and 
2005b; Scerri, 2004, 2007a and 2007b; Scerri \& McIntyre, 1997; Vemulapalli, 2006). Chemical models contain approximations and presumptions and hence are level specific and limited in their scope (Erduran \& Scerri, 2002). According to Erduran (2001), understanding that models are used as a way to explain chemical phenomena, and that models change because of the limitations innate to them, is essential in understanding chemical models. It is also essential to understand that chemical models are not necessarily mathematically postulated from the laws of physics (Scerri \& McIntyre, 1997). None of the analyzed curricula take into account the fact that chemical models are limited in their scope or explicitly define how chemistry differs from other sciences (e.g. physics or biology).

Looking at the phases of experimental research mentioned in the syllabi (see Table 2), the first two (defining research question and forming hypothesis) can be seen as the strategies of science, as defined by Elkana (2000/1970). The strategies of science set the core questions and conceptual presuppositions for research. The tactics of science include the other phases of research. The design of new research questions and models requires creativity. This creativity is usually seen as a crucial part of the nature of science (e.g. Lederman, 2004; McComas \& Olson 1998, Osborne et al., 2003). Although the Swedish and Norwegian syllabi include the strategic phases, none of the national frame curricula mention scientific creativity in the aims of chemistry education. Concentrating on the tactics of science and leaving out the strategies and creativity, can give the wrong impression of the attributes required for a scientific researcher.

As science is constituted by texts, and as TV, newspapers, magazines, and the Internet are primary sources of technical and scientific information, there is a need to emphasize the skills of interpreting, analyzing, and critically reading science texts (Norris \& Phillips, 2002). Several research studies have shown that canonical scientific knowledge is not directly applicable to science-related issues in everyday life and in science-related jobs (see Aikenhead, 2005; Chin, Munby, Hutchinson, Taylor \& Clark, 2004; Duggan \& Gott, 2002; Gott, Duggan \& Johnson, 1999; Lottero-Perdue $\&$ Brickhouse, 2002). Chemistry and other sciences closely related to chemistry (such as biochemistry and nanotechnology) are developing at such a rate that it is close to impossible to know what kinds of conceptual knowledge will be needed in the future. Most of the science related conceptual understanding used in everyday life and in science-related occupations is learned later on (Duggan \& Gott, 2002). Concentrating on learning procedural knowledge seems to be more useful than focusing on declarative knowledge in the form of scientific theories and models (Chin, Munby, Hutchinson, Taylor \& Clark, 2004; Duggan \& Gott, 2002).

In science-related jobs the key component of procedural knowledge are concepts of evidence, which are connected with the skills of scrutinizing reliability and the validity of evidence (Aikenhead, 2005; Duggan \& Gott, 2002). Even though the skills associated with evaluating reliability are mentioned in all the curricula under study, there should be more emphasis on the concepts of risk and probability, which are central in making societal and personal decisions related to science (Duggan \& Gott, 2002), and also on accessing and critically evaluating new scientific knowledge published in popular media and on the Internet. Scrutinizing reliability and validity should be done not only on a level of the substantive content of science, but also by concentrating on things such as determining degree of certainty being expressed, and the scientific status of statements (Norris \& Phillips, 2002).

\section{Societal character of chemistry}

Every national frame curricula in this study is consistent with the view that students should understand the huge impact applications derived from chemical research have on our society and acknowledge that chemical knowledge can be used as a basis for societal decisions (see Table 3). However, every frame curricula under study seems to define the role of chemistry in society on the instrumental level - as a tool to produce new applications. Especially, the Finnish curriculum 
fails to acknowledge the relation between chemistry and society or chemistry and technology as being interdependent. For example, societal interests in the form of funding and legislation and the technical development of instrumentation have radically changed the way chemical research is done (Baird, 2000). None of the curricula in this study take into account the cooperation and collaboration of the research community in the development of chemical knowledge, which is usually seen as a central element of the nature of science (e.g. McComas \& Olson 1998, Osborne et al., 2003). The development of instrumentation is not mentioned explicitly, either.

Ethics is mentioned in all the national frame curricula in this study, but again only on an instrumental level - as a tool for making informed decisions. Only the Norwegian national frame curriculum addresses the ethical decisions that chemists have to face. (See Table 3.) Also all the curricula under study present chemical technology as almost exclusively beneficial for human beings. It is seen as a way to support sustainable development and to enhance living conditions.

\section{Chemistry as a technological practice}

Of all sciences, chemistry is perhaps the most closely related to industry and technology. The selfimage of chemists' has always been determined by a symbiotic relationship between the science and industry (Laszlo, 2006). In addition to technological research interests chemistry has a laboratory core that is technological. Sjöström (2007) argues that, as chemists are not only interested in molecules' characters and behaviors, but also in generating wholly new molecules and structures or methods of production, chemistry is as closely related to technology as it is to science. He quotes Schummer (1999): "All received concepts to distinguish between science and technology fail, if we try to apply them to chemistry."

The ethical issues concerning the development of novel technologies (e.g. biotechnology and nanotechnology) are not necessary as novel as usually thought or limited to only certain recent areas of research (MacDonald, 2004). As many of the ethical or societal issues related to chemistry are much less controversial than issues in biochemistry, genetics or nanotechnology, chemistry education could offer a way to develop scientific and technological literacy without creating an overtly negative image of science and technology. Jones (2007) writes (in terms of biotechnology but it also applies in terms of chemistry) that students should be "introduced to a wider range of ideas and values that both constrain and promote science and technological developments". Technology is not a subset of or subservient to science. A broader view of technology allows exploration of societal values and beliefs and how these influence the way technological and scientific developments take place. Technological literacy should include understanding the impact that existing and emerging technologies will have upon cultural development, as well as the potential and actual consequences these technologies will have upon the environment (Dakers, Dow \& de Vries, 2007).

The use of new technology implies a risk that needs to be considered before its use by society (Beck, 1992). As risk is an inherent characteristic of the technological society, presenting technology as exclusively beneficial for human beings is not only a naïve view of technology but also manipulative and misleading (Santos, 2008). The myth that technology and science are neutral, value-free, and objective, and that technical expertise can solve any problem could be tackled by discussing the possible consequences of applying scientific ideas by including the notions of risk and the assessment of the benefits (Lloyd \& Wallace, 2004). Discussing the societal and ethical factors affecting technological practice could expand the view students have of chemistry as a scientific and technological practice, and its significance.

If we leave out chemists' ethic responsibilities and discussion of the impact that existing and emerging technologies will have upon cultural development we dehumanize chemical research. If our intent is to produce students with not just adequate skills for coping in a society, but students 
capable of critically considering the premises of the system - 'the rules of the game', critical consideration and reflection on the role of chemistry in society have to be taken into account (Sjöström, 2007).

\section{Conclusions and implications}

Chemistry syllabi from the Nordic frame curricula analyzed in this study take into account aims related to nature of chemistry quite similarly. The Finnish frame curriculum (Finnish National Board of Education, 2003) is missing several important elements of nature of chemistry mentioned in other analyzed frame curricula. The themes the Finnish chemistry frame curriculum should take better into account are: the tentative nature of chemical knowledge, defining research problem and forming hypothesis as phases of chemical research, the way theories and models affect experimental research, the impact of chemical knowledge on our culture and worldview, and the ethical responsibilities of chemical research. A few of the themes are only mentioned in one of the curricula: the research phase of defining research questions is explicitly mentioned only in the Swedish national frame curricula (National Agency for Education, 2000), and the ethical decisions that the chemists have to face are mentioned only in the Norwegian national frame curriculum (Norwegian Directorate for Education and Training, 2006).

On comparing the three national frame curricula with research on the nature of chemistry, we found several themes that in our opinion should be made more explicit in the aims of upper secondary school chemistry education. Themes that are not explicitly mentioned in any of the curricula under study include: $i$ ) the limits of the chemical models and theories, $i i$ ) the relationship between chemistry and other natural sciences, iii) the importance of creativity in chemical research, $i v)$ the concepts of evidence in science texts, $v$ ) the social nature of chemical research, and $v i$ ) chemistry as a technological practice.

Chemistry as a scientific discipline is constantly evolving and transforming. If the goal of education is to produce scientifically and technologically literate students, there is clearly a need to take the nature of chemistry better into account when designing new chemistry syllabi.

At the final stage of the curriculum process, teachers implement the aims and objectives defined by the national frame curricula. Hence, teachers' views on the aims of education are of enormous importance in developing chemistry education. Teachers bring their own value-set to the task of selecting and implementing the intended curriculum (Hildebrand, 2007). To make informed curricular decisions, there is a need to teach future chemistry teachers, not only ontological chemical knowledge, but also philosophical and sociological perspectives of chemical practice and reflection on the role of chemistry in society. To address nature of chemistry related issues there is a need to include discussion on the NOS related topics and teacher-scientist interaction to chemistry teachers' education (Vesterinen \& Aksela, 2009). As the final curricular decisions are always made by the teachers who put them into practice, further study on how teachers' values and views on the nature of chemistry affect the learning goals teachers set for their students should be undertaken.

During the implementation of curriculum, also the students are engaged as partners in the enactment process. Students mediate what they take from the enacted curriculum into their lives. (Hildebrand, 2007) Hence there is need to study, how students perceive the goals and aims of chemistry education, and what skills they think would be worthwhile for their lives. 


\section{REFERENCES}

Abd-El-Khalick, F. (1998). The influence of history of science courses on students' conceptions of the nature of science. Unpublished doctoral dissertation Oregon State University, Oregon.

Abd-El-Khalick, F. \& Akerson, V.L. (2004). Learning as conceptual change: Factors mediating the development of preservice elementary teachers' views of the nature of science. Science Education, 88, 785-810.

Abd-El-Khalick, F., \& Lederman, N. G. (2000). Improving Science Teachers' Conceptions of Nature of Science: a Critical Review of the Literature. International Journal of Science Education, 22, 665-701.

Akerson, V.L., Abd-El-Khalick, F., \& Lederman, N.G. (2000). Influence of a Reflective Explicit Activity-based Approach on Elementary Teachers' Conceptions of Nature of Science. Journal of Research in Science Teaching, 37, 295-317.

Aikenhead, G. S. (2005). Science-Based Occupations and the Science Curriculum: Concepts of Evidence. Science Education, 89, 242-275.

Baird, D. (2000). Analytical Instrumentation and Instrumental Objectivity. In N. Bhushan, \& S. Rosenfeld (Eds.), Of Minds and Molecules: New Philosophical Perspectives on Chemistry (pp. 90-113). New York, NY: Oxford University Press.

Beck, U. (1992). Risk society: Towards a new modernity. London: Newbury Park.

Bell, R.L., Blair, L.M., Crawford, B.A., \& Lederman, N.G. (2003). Just do it? Impact of a Science Apprenticeship Program on High School Students' Understandings of the Nature of Science and Scientific Inquiry. Journal of Research in Science Teaching, 40, 487-509.

Chin, P., Munby, H., Hutchinson, N. L., Taylor, J., \& Clark, F. (2004). Where's the Science? Understanding the Form and Function of Workplace Science. In E. Scanlon, P. Murphy, J. Thomas, \& E. Whitelegg (Eds.), Reconsidering Science Learning (pp. 118-134). London: Routledge Falmer.

Dakers, J.R. (2006a). Introduction: Defining Technological Literacy. In J.R. Dakers (Ed.), Defining Technological Literacy: Towards an Epistemological Framework, pp. 1-2. New York, NY: Palgrave Macmillan.

Dakers, J.R. (2006b). Towards a Philosophy for Technology Education. In J.R. Dakers (Ed.), Defining Technological Literacy: Towards an Epistemological Framework, pp. 145-158. New York, NY: Palgrave Macmillan.

Dakers, J.R., Dow, W.J., \& de Vries, M.J. (2007). Introduction. In J.R. Dakers, W.J. Dow and M.J. de Vries (Eds.), Pupils Attitudes Towards Technology 2007, International Conference on Design and Technology Educational Research, Teaching and Learning Technological Literacy in the Classroom, p. 7. Glasgow: University of Glasgow.

Dalgety, J., Coll, R.K., \& Jones, A. (2003) Development of Chemistry Attitudes and Experiences Questionnaire (CAEQ). Journal of Research in Science Teaching, 40, 649-668.

Duggan, S., \& Gott, R. (2002). What Sort of Science Education Do We Really Need? International Journal of Science Education, 24, 661-679.

Elkana, Y. (2000/1970). Science, Philosophy of Science and Science Teaching. Science and Education, 9, 463-485. (Originally published in Educational Philosophy and Theory, 1970, Vol. 2.)

Erduran, S. (2001). Philosophy of Chemistry: An Emerging Field with Implications for Chemistry Education. Science \& Education, 10, 581-593.

Erduran, S. \& Duschl, R.: 2004, Interdisciplinary Characterization of Models and the Nature of Chemical Knowledge in the Classroom. Studies in Science Education, 40, 111-144.

Erduran, S., \& Scerri, E. (2002). The Nature of Chemical Knowledge and Chemical Education. In J. K. Gilbert, O. De Jong, R. Justi, D. F. Treagust, \& J. Van Driel (Eds.), Chemical Education: Towards Research-based Practice (pp. 7-28). Dordrecht: Kluwer.

Finnish National Board of Education (2003). National core curriculum for upper secondary schools 2003. Helsinki: Finnish National Board of Education. 
Finnish National Board of Education (2004). National core curriculum for basic education 2004. Helsinki: Finnish National Board of Education.

Friedrich, B. (2004). Hasn't it? A Commentary on Eric Scerri's Paper 'Has Quantum Mechanics Explained the Periodic Table' Now Published Under Title 'Just How Ab Initio Is Ab Initio Quantum Chemistry?' Foundations of Chemistry, 6, 117-132.

Gott, R., Duggan, S., \& Johnson, P. (1999). What do practising applied scientists do and what are the implications for science education? Research in Science \& Technological Education, 17, 97-107.

Hildebrand, G. M. (2007). Diversity, Values and the Science Curriculum: Which Curriculum? What Values? In D. Corrigan, J. Dillon, \& R. Gunstone (Eds.), The Re-Emergence of Values in Science Education (pp. 89-100). Rotterdam: Sense Publishers.

Hodson, D. (2003). Time for Action: Science Education for an Alternative Future. International Journal of Science Education, 25, 645-670.

Huberman, A. M., \& Miles, M. B. (1994). Data Management and Analysis Methods. In N. K. Denzin, \& Y. S. Lincoln (Eds.), Handbook of Qualitative Research. Thousand Oaks: Sage.

Jones, A. (2007). The Valuing of Technology in the Science Curriculum: Biotechnology as an Example. In D. Corrigan, J. Dillon, \& R. Gunstone, (Eds.) The Re-Emergence of Values in Science Education, (pp. 89-100). Rotterdam: Sense Publishers.

Khishfe, R., \& Abd-El-Khalick, F. (2002). The Influence of Explicit Reflective versus Implicit Inquiry-oriented Instruction on Sixth Graders' Views of Nature of Science. Journal of Research in Science Teaching, 39, 551-578.

Krageskov Eriksen, K. (2002). The Future of Tertiary Chemical Education - A Bildung Focus. Hyle: International Journal for Philosophy of Chemistry, 8, 35-48.

Laszlo, P. (2006), On the self-image of chemists, 1950-2000. HYLE: International Journal for Philosophy of Chemistry, 12, 99-130.

Lederman, N. G. (2004). Syntax of Nature of Science Within Inquiry and Science Instruction. In L. B. Flick \& N. G. Lederman (Eds.), Scientific Inquiry and Nature of Science (pp. 301-317). Dordrecht: Kluwer.

Lederman, N. G., Abd-El-Khalick, F., Bell, R. L., \& Schwartz, R. (2002). Views of nature of science questionnaire: Toward valid and meaningful assessment of learners' conceptions of nature of science. Journal of Research in Science Teaching, 39, 497-521.

Lloyd, D. \& Wallace, J. (2004). Imaging the Future of Science Education: The Case for Making Futures Studies Explicit in Student Learning. Studies in Science Education, 40, 139-178.

Lombardi, O. \& Labarca, M. (2007). The Philosophy of Chemistry as a New Resource for Chemistry Education. Journal of Chemical Education, 84, 187-192.

Lottero-Perdue, P. S., \& Brickhouse, N.W. (2002). Learning on the Job: The Acquisition of Scientific Competence. Science Education, 86, 756-782.

McComas, W.F. \& Olson, J. K. (1998). The Nature of Science in International Science Education Documents. In W. F. McComas (Ed.), The Nature of Science in Science Education: Rationales and Strategies (pp. 41-52). Dordrecht: Kluwer.

MacDonald, C. (2004). Nanotech is Novel, The Ethical Issues Are Not. The Scientist, 18(3), 8.

National Agency for Education (2001). Natural Science Programme GY 2000:14. Västerås: National Agency for Education and Fritzes.

National Agency for Education (2009). Syllabuses for the compulsory school, Second edition. Västerås: National Agency for Education and Fritzes.

Niaz, M. (2008). What 'ideas-about-science' should be taughtin school science? A chemistry teachers' perspective. Instructional Science, 36, 233-249.

Norris, S. P., \& Phillips, L. M. (2002). How Literacy in Its Fundamental Sense Is Central to Scientific Literacy. Science Education, 87, 224-240.

Norwegian Directorate for Education and Training (2006). Chemistry - Programme subject in programmes for specialization in general studies. Hamar: Norwegian Directorate for Education and Training. Retrieved April 1. 2009 from: http://www.utdanningsdirektoratet.no/upload/ 
larerplaner/Fastsatte_lareplaner_for_Kunnskapsloeftet/english/Natural_science_mathematics/Chemistry.rtf

Osborne, J., Collins, S., Ratcliffe, M., Millar, R. \& Duschl, R. (2003). What 'Ideas-about-Science' Should Be Taught in School Science? A Delphi Study of the Expert Community. Journal of Research in Science Education, 40, 692-720.

Ostrovsky, V. N. (2001). What and How Physics Contributes to Understanding the Periodic Law? Foundations of Chemistry, 3, 145-182.

Ostrovsky, V. N. (2005a). Towards a Philosophy of Approximations in the 'Exact' Sciences. HYLE: International Journal for Philosophy of Chemistry, 11, 101-126.

Ostrovsky, V. N. (2005b). On Recent Discussion Concerning Quantum Justification of the Periodic Table of the Elements. Foundations of Chemistry, 7, 235-239.

Santos, W. L. P. dos (2008). Scientific Literacy: A Freirean Perspective as a Radical View of Humanistic Science Education. Science Education, 92, 361-382.

Schummer, J. (1999). Coping with the Growth of Chemical Knowledge - Challenges for Chemistry Documentation, Education, and Working Chemists. Educación Química, 10, 92-101.

Scerri, E. R. 2003. Philosophical Confusion in Chemical Education Research. Journal of Chemical Education, 80, 468-474.

Scerri, E. R. (2004). How Ab initio Is Ab initio Quantum Chemistry? Foundations of Chemistry, 6, 93-116.

Scerri, E. R. (2007a). The Periodic Table: Its Story and Its Significance. Oxford University Press, New York.

Scerri, E. R. (2007b). The Ambiguity of Reduction. HYLE: International Journal for Philosophy of Chemistry, 13, 67-81.

Scerri, E. R. \& McIntyre, L. 1997. The Case for Philosophy of Chemistry. Synthese, 111, 213-232.

Solomon, J., Duveen, J., Scot, L., \& McCarthy, S. (1992). Teaching about the Nature of Science through History: Action Research in the Classroom. Journal of Research in Science Teaching, 29, 409-421.

Sjöström, J. (2007). The Discourse of Chemistry (and Beyond). HYLE: International Journal for Philosophy of Chemistry, 13, 83-97.

Vemulapalli, G. K. (2006). Physics in the Crucible of Chemistry: Ontological Boundaries and Epistemological Blueprints. In D. Baird, E. Scerri, \& L. McIntyre (Eds.), Philosophy of Chemistry: Synthesis of a New Discipline (pp. 191-204). Dordrecht: Springer.

Vesterinen, V.-M. \& Aksela, M. (2009). A Novel Course of Chemistry as a Scientific Discipline: How Do Prospective Teachers Perceive Nature of Chemistry through Visits to Research Groups? Chemical Education Research and Practice, 10, 132-141. 